\title{
Earning Management and the Role of Accounting Conservatism at Firm Level
}

\author{
Abdul Haque ${ }^{1}$, Azhar Mughal ${ }^{1} \&$ Zohaib Zahid $^{1}$ \\ ${ }^{1}$ COMSATS Institute of Information Technology, Lahore, Pakistan \\ Correspondence: Abdul Haque, Department of Management Sciences, COMSATS Institute of Informtaion \\ Technology, Lahore Campus, Postal Code 54000, Lahore, Pakistan. Tel: 92-42-111-001-007 ext 119. E-mail: \\ ahaque@ciitlahore.edu.pk,m_azhar786@hotmail.com
}

Received: December 7, 2015

Accepted: January 19, $2015 \quad$ Online Published: January 25, 2016

doi:10.5539/ijef.v8n2p197

URL: http://dx.doi.org/10.5539/ijef.v8n2p197

\begin{abstract}
Accounting conservatism and earning management are very much pervasive in financial reporting practices. Therefore, this research study aims to investigate the relationship between accounting conservatism and earning management by using a sample of 317 non-financial Pakistani firms consisting of 4204 firm-years over the period 1999-2013. Conservatism at the firm level is estimated by using the C-Score measure and earning management is observed by calculating discretionary accruals. The estimated results show that one fourth ( 86 firms) of the sample is highly conservative; out of these $76 \%$ ( 65 firms) showed least earning management (Earning management $<\mathrm{Q}_{1}$ ) while $24 \%$ (21 firms) showed moderate earning management $\left(\mathrm{Q}_{1}<\right.$ Earning management $\left.<\mathrm{Q}_{3}\right)$. On the other hand, in the least conservative group, $71 \%$ (57 firms) showed high earning management (Earning management $>\mathrm{Q}_{3}$ ) and $29 \%$ (23 firms) showed earning management at a moderate level $\left(\mathrm{Q}_{1}<\right.$ Earning management $\left.<\mathrm{Q}_{3}\right)$. Thus the findings of the study reveal a negative association between accounting conservatism and earning management.
\end{abstract}

Keywords: earning management, accounting conservatism, discretionary accruals

\section{Introduction}

Earnings or net income is an important item in the financial statements and is regarded as a performance measure for any business. Rise in earnings of an organization signal an increase in the value of a business and a fall in earnings signal a decrease (Lev, 1989). Given the importance of earnings/income it is not surprising that the company's management has a vital interest in, how to report earnings? This is the reason that the management needs to understand the effect of different accounting choices which are the decisions that affect the accounting numbers in a specific way (Fields, Lys, \& Vincent, 2001). Earning management (EM) occurs when managers intervene into the overall financial reporting process in order to either present a positive picture to the stakeholders about the company's performance or in order to affect contracts that depends on the financial statements (Healy \& Wahlen, 1999). Moreover, this intervention into the reporting process by the manager is likely to obtain some personal benefits (Schipper, 1989). Similarly, managers are likely to report firm's current income at a higher level when there are chances that the firm is not able to meet its debt covenants. In order to avoid the violation of certain constraints contained in the debt contracts such as debt to equity ratio, the managers take action to report higher current income as it will reduce firm's default risk (DeAngelo, H., DeAngelo, L., \& Skinner, 1994). Thus, there exists a conflict of interest among these stakeholders which is due to information asymmetry just like the concept given by agency theory. Moreover the managers take opportunistic decisions, creating a moral hazard problem because shareholders don't have much information for monitoring the actions of management. In order to reduce such information asymmetry and to counterbalance such opportunistic behavior by the management there is a need to use accounting choices. Dechow and Skinner (2000) mentioned different accounting choices and from among those, accounting conservatism is the oldest principle (Sterling, 1967). Under conservative accounting expenses and losses are recorded in a timelier manner than the income or gains (Givoly, Hayn, \& Natarajan, 2007). In this way it helps to limit the opportunistic reporting behavior and is beneficial for the users of financial statements. It also decreases the moral hazard (ethical risk) and the adverse selection problem that exists between management and investors or management and lenders, by confining the managers from distorting incomes so that investors and lenders are not misled and make unfavorable investment decisions (Ross, 2003). According to Ross L. Watts (2003) the adoption of accounting conservatism can reduce litigation risk, present value of tax liabilities and can avoid 
criticism and other political costs.

Previously various researchers have studied the relationship between $E M$ and accounting conservatism and provide somewhat mixed findings. According to Ball and Shivakumar (2005) accounting conservatism can decrease the opportunistic behavior of the manager while disclosing results optimistically. LaFond and Watts (2008) showed that accounting conservatism restricts the accounting manipulation and reduces the adverse effects of information asymmetry. Lara, Osma, and Penalva (2012) found that the firms, which are more conservative have less chances of being engaged in EM. Similarly, another study by (Abed, Al-Badainah, \& Serdaneh, 2012) showed that accounting conservatism and the size are inversely related to EM. While, Lobo, Parthasarathy, and Sivaramakrishnan (2008) said that the financial statements following conservative approach have more $E M$ and show a positive relationship. Similarly, Kwon, Yin, and Han (2006) also indicated that highly conservative firms are more likely to be engaged in $E M$ again showing a positive relationship.

The above mentioned inconclusive evidence from the literature provides an opportunity to report some latest findings. In order to fill the gap we study the relationship between accounting conservatism and $E M$ by taking a panel of 317 non-financial Pakistani listed firms over the period 1999-2013. The findings of the study contribute in literature in many ways. Firstly, this research study measures accounting conservatism at firm level by using C-Score measure developed by Khan and Watts (2009). Secondly, this study divides the firms, according to their conservatism level into highly conservative $\left(\mathrm{C}\right.$-Score $\left.>\mathrm{Q}_{3}\right)$ and lesser conservative firms $\left(\mathrm{C}\right.$-Score $\left.<\mathrm{Q}_{3}\right)$. Thirdly, it investigates the relationship between accounting conservatism and $E M$ and finds that there are $76 \%$ highly conservative firms which are engaged in $E M$ and remaining $24 \%$ of the firms are showing moderate $E M$, highlighting a negative association between them. On the other hand $71 \%$ of the least conservative firms have shown that they are more involved in $E M$ while $29 \%$ of them are showing moderate $E M$, again showing an inverse relationship. Thus the finding of the study is an addition to the existing research with reference to Pakistan as there are not enough studies available related to the topic under discussion.

\section{Literature Review}

\subsection{Earning Management (EM)}

$E M$ has gained so much importance throughout the world that there is a vast amount of research in which it has been discussed. Numerous definitions of $E M$ have been reported in the literature. It is a purposeful intervention in the financial reporting process with the intention to obtain some private benefits (Schipper, 1989). According to Ross L. Watts and Zimmerman (1990) managers make use of their discretion over financial statement numbers either to raise the wealth of all contracting parties or to make themselves better off. The widely used definition of $E M$ as stated by (Healy \& Wahlen, 1999) is given below.

"Earnings management occurs when managers use judgment in financial reporting and in structuring transactions to alter financial reports to either mislead some stakeholders about the underlying economic performance of the company or to influence contractual outcomes that depend on reported accounting numbers."

Stolowy and Breton (2004) said that EM is account manipulation and management use its discretion in making accounting choices or in designing the transactions so that they can affect the possibilities of wealth transfer among different stakeholders.

Marquardt and Wiedman (2004) found that the firms issuing equity, recognize earnings quickly and manage their earnings upwards while the firms that are engaged in management buyouts show the contrary effect and manage their earnings downwards. Peasnell, Pope, and Young (2005) investigated the relationship between board monitoring of UK companies and the $E M$. They found that when the proportion of outside members is high in a board, income increasing $E M$ will be less when pre-managed earnings fall below a certain level. On the other hand, when pre-managed earnings are higher than a specific limit by a greater margin, there will be no income decreasing $E M$. Moreover, audit committee was found to have no association with the $E M$.

Zang (2011) analyzed the sample taken from Compustat database and discussed about the tradeoff between real $E M$ and accrual based $E M$ by the management. She found that firms use more accrual based $E M$ compared to real manipulation when the later is more costly. She argued that both are substitutes and management uses the easiest way to manage earnings.

As for Dyreng, Hanlon, and Maydew (2012), they studied a sample of multinationals from US and found that firms manage their domestic earnings more than the foreign incomes. Moreover, they found that subsidiaries engage in $E M$ is more in countries where rule of law is weak as compared to countries where it is strong.

In the Tunisian context, Chekili (2012) studied a sample of Tunisian firms and tried to explore the relationship between corporate governance mechanisms and EM. In this study existence of non-executive directors in a board, 
board size and also the existence of chief executive officer appointed by the state found to have significant impact on $E M$.

Hazarika, Karpoff, and Nahata (2012) examined the relationship between $E M$ and the risk of job loss. They found that management tends to punish the executives actively who are engaged in aggressive $E M$, because such manipulations can result in costly external consequences. Moreover CEO's tenure has a negative association with the earning manipulation.

\subsection{Accounting Conservatism}

Accounting conservatism is defined as "the accountant's tendency to require a higher degree of verification to recognize good news as gains than to recognize bad news as losses" (Basu, 1997). According to Ross L Watts (2003), an extreme form of conservatism can be expressed by a saying that "anticipate no profits, but anticipate all losses." Conservatism can also be referred to as prudence concept (Lin, Wu, Fang, \& Wun, 2014). A higher level of confirmation is required in order to recognize profits as compared to expenses. Profits should be recognized after verification at a greater level as compared to expenses (Ross, 2003). Accounting conservatism results in more timely recognition of expenses and losses as compared to gains and incomes (Givoly et al., 2007). Conservatism has affected the accounting practice for at least five centuries (Basu, 1997). Ross L. Watts (2003) suggests that accounting practice has become more conservative especially in the last three decades. Ball, Robin, and Sadka (2008) studied whether the debt market or equity market has any effect on financial reporting. They found that debt market demand more conservatism as compared to the equity market. LaFond and Watts (2008) say that accounting conservatism is used to counterbalance the problem that arises due to information asymmetry.

In a research by Hamdan, Abzakh, and Al-Ataibi (2011), they studied the conservatism level in public sector organizations listed on the Kuwait stock exchange. They said that the public sector companies show a reasonable conservatism level under accounting standard regulations. They found that big organizations are less conservative than small ones. Moreover the firms with higher leverage are less conservative than the firms with less leverage.

In the case of China, Z. J. Lin and Tian (2012) investigated the impact of accounting conservatism and IPO underpricing by taking a sample from Shanghai and Shenzhen stock exchanges. They said that accounting conservatism reduces the information asymmetry faced by IPO firms and it also mitigates the underpricing of initial public offering. In addition, they found that IPO firms with higher information asymmetry require a high degree of accounting conservatism.

Kravet (2014) found that there exists a negative relation between manager's behavior and accounting conservatism, when making risky investments. He argued that conservative accounting decreases the managerial incentives in making riskier investments.

\subsection{Accounting Conservatism and Earning Management}

Recent studies have shown that accounting conservatism puts limits on the $E M$ and higher the accounting conservatism and lower the $E M$.

A study conducted by Chen, Hemmer, and Zhang (2007) shows that management manipulates earnings to meet the investor's expectations which results in inefficient $E M$ but accounting conservatism reduces such inefficiency by decreasing the incentive to manipulate earnings.

Abed et al. (2012) investigated a sample of Jordanian manufacturing companies that was taken from Amman stock exchange. They say that level of conservatism varies from company to company. In addition conservatism and size have negative association with the $E M$.

Lara et al. (2012) used discretionary accruals to estimate $E M$ in a large U.S sample of firms for the period 1991-2010 and found a negative relationship between accounting conservatism and EM. She said that more conservative firms have less chance of being involved in earning manipulation.

F. Lin et al. (2014) used Benford's Law for the estimation of EM in actual earning numbers in a sample containing 47,721 firm year observations for the period 1996-2012. They found that the firms adopting high degree of conservatism are less likely involved in earning manipulation.

Lobo et al. (2008) on the other hand reported a positive relationship between $E M$ and level of conservatism and showed that the financial statements that have been prepared following conservative approach have more $E M$.

Kwon et al. (2006) also indicated a positive association between accounting conservatism and $E M$ and showed that the high-tech firms that are highly conservative have greater chances of being engaged in $E M$ than the lesser conservative high-tech firms which have lesser chances of being involved in $E M$. 


\section{Method}

Earlier studies have examined the relationship between $E M$ and accounting conservatism and found that highly conservative firms have less $E M$ showing an inverse relationship. Some other studies have shown that highly conservative firms have greater chances of being engaged in EM showing a positive relationship. As scholars have different opinions on the link between $E M$ and accounting conservatism, therefore this research study is an attempt to highlight the association between $E M$ and conservatism.

\subsection{Measurement of Accounting Conservatism}

Beaver and Ryan (2005) indicated the difference between two types of accounting conservatism i.e.; Conditional and unconditional conservatism. They showed that conditional conservatism is related to the asymmetric timeliness of earnings. Basu (1997) measure of asymmetric timeliness is not suitable to estimate the firm level conservatism. Therefore this study uses Khan and Watts (2009) model which is a firm year measure of conditional accounting conservatism. This measure is also referred as a C-Score measure. C-Score measure has roots into the Basu (1997) model. That is given by

$$
\operatorname{Earn}_{i t}=\beta_{1}+\beta_{2} D_{i t}+\beta_{3} R_{i t}+\beta_{4} D_{i t} R_{i t}+\varepsilon_{i t}
$$

Where $i$ represents firm and $t$ represents year, Earn represents earnings, $\mathrm{R}$ represents returns which is measuring news, $\mathrm{D}$ is dummy variable which is equal to 1 if $\mathrm{R}<0$ and equal to 0 otherwise, and $\epsilon$ is the error term. $\beta_{3}$ represents the good news timeliness measurement while $\beta_{4}$ represents the measurement of conservatism (bad news over good news), and the bad news timeliness in total is given by $\beta_{3+} \beta_{4}$.

For the estimation of good news timeliness and bad news timeliness at firm level, Khan and Watts (2009) indicated that good news timeliness and bad news timeliness both are linear functions of firm year characteristics. They referred good news timeliness as G-Score and bad news timeliness as C-Score.

$$
\begin{aligned}
& \text { G-Score }=\beta_{3}=\mu_{1 t}+\mu_{2 t} \text { Size }_{i t}+\mu_{3 t} \text { MTB }_{i t}+\mu_{4 t} \text { Lev }_{i t} \\
& \text { C-Score }=\beta_{4}=\lambda_{1 t}+\lambda_{2 t} \text { Size }_{i t}+\lambda_{3 t} \text { MTB }_{i t}+\lambda_{4 t} \text { Lev }_{i t}
\end{aligned}
$$

Where Size is $\ln$ (Total Assets), MTB is calculated as the market value of equity / book value and Lev is total debts / total assets. Equation 2 and 3 represents firm year measure of G-Score and C-Score respectively.

For the estimation of $\mathrm{C}$ and $\mathrm{G}-\mathrm{Score}$ the annual cross sectional regression model is given by

$$
\begin{aligned}
\operatorname{Earn}_{i t}=\beta_{1}+\beta_{2} D_{i t}+R_{i t}\left(\mu_{1 t}\right. & \left.+\mu_{2 t} \operatorname{Size}_{i t}+\mu_{3 t} M T B_{i t}+\mu_{4 t} \operatorname{Lev}_{i t}\right)+D_{i t} R_{i t}\left(\lambda_{1 t}+\lambda_{2 t} \operatorname{Size}_{i t}+\lambda_{3 t} M T B_{i t}+\lambda_{4 t} \operatorname{Lev}_{i t}\right)+\left(21 t \operatorname{Size}_{i t}\right. \\
& \left.+2_{2 t} M T B_{i t}+23 t \operatorname{Lv}_{i t}+2{ }_{4 t} D_{i t} \operatorname{Size}_{i t}+25 D_{i t} M T B_{i t}+2 \sigma D_{i t} \operatorname{Lev}_{i t}\right)+\epsilon_{i t}
\end{aligned}
$$

Substitution of equation (2) \& (3) into (1) results in equation (4).

\subsection{Measurement of Earning Management (EM)}

$E M$ has a nature that it is unobservable, therefore researchers use proxies for its estimation. Discretionary accruals is the most commonly used proxy for $E M$ as discretionary accrual represents managerial discretion. In this study the method developed by Chan, Chan, Jegadeesh, and Lakonishok (2001) is used because this model does not require an adequately long time series data for estimation of discretionary accruals. The model is given by:

$$
\begin{gathered}
\text { DiscAccr }_{i t}=\text { Accrual }_{i t}-\text { NormalAccr }_{i t} \\
\text { NormalAccr }_{i t}=\frac{\sum_{k=1}^{5} \text { Accrual }_{i, t-k}}{\sum_{k=1}^{5} \text { Sales }_{i, t-k}} \text { Sales }_{i t}
\end{gathered}
$$

Where $i$ represents firm while $t$ represents year. DiscAccr is the Discretionary accruals. Accrual represents the total accrual. NormalAccr is the normal accrual and Sales represents the total sales.

Accrual is measured following Sloan (1996) as:

$$
\text { Accrual }=\Delta \text { Cassets }-\Delta \text { Cliabilities }- \text { Dep }
$$

Where $\Delta$ Cassets is the change in non-cash current asset, $\Delta$ Cliabilities is the change in current liability (short term debt and tax payable not included) and Dep represents the depreciation \& amortization. Accrual is scaled by average total asset.

Equation 7 is used to calculate total accrual. Equation 6 is used for the calculation of normal accrual in which ratio of five year moving average of accrual to a five year moving average of sales is used for smoothing purposes. Then equation 5 is used for the calculation of the discretionary portion of accruals. 


\section{Sample and Data Collection}

The data for research purpose is collected from web sources of various financial and economic information providers. Data set comprises of all Pakistani firms quoted on the Karachi stock exchange (KSE) retrieved from Annual Balance Sheet analysis reports published by State Bank of Pakistan along with the published annual financial reports of individual companies. Share price data and returns of different firms are obtained from the KSE data portal and Business Recorder.

The data related to financial firms, firm years with variables having missing values and firm year observations having negative (-ve) book value of equity are deleted. This results in a sample of 4204 firm year observations from 1999 to 2013. Table 1 shows the descriptives for the whole sample, in which mean, SD (standard deviation), median, first and third quartiles are mentioned.

Table 1. Descriptive statistics

Panel A. Variables used to calculate C-score

\begin{tabular}{lccccc}
\hline & Mean & SD & $\mathrm{Q}_{1}$ & Median & $\mathrm{Q}_{3}$ \\
\hline Earn & 0.068 & 0.147 & 0.003 & 0.047 & 0.128 \\
$\mathrm{R}$ & 0.446 & 2.619 & -0.090 & 0.245 & 0.661 \\
Size & 21.238 & 1.617 & 20.159 & 21.095 & 22.206 \\
MTB & 1.497 & 6.424 & 0.338 & 0.676 & 1.413 \\
Lev & 0.827 & 11.080 & 0.452 & 0.626 & 0.767 \\
\hline
\end{tabular}

Panel B. Variables used to estimate discretionary accruals

\begin{tabular}{lccccc}
\hline & Mean & SD & $\mathrm{Q}_{1}$ & Median & $\mathrm{Q}_{3}$ \\
\hline Cassets & 0.425 & 0.226 & 0.257 & 0.410 & 0.576 \\
Cliabilities & 1.264 & 14.200 & 0.309 & 0.478 & 0.646 \\
$\Delta$ Cassets & 0.028 & 0.171 & -0.032 & 0.021 & 0.094 \\
$\Delta$ Cliabilities & 0.029 & 0.536 & -0.036 & 0.034 & 0.123 \\
Dep & 0.110 & 3.587 & 0.024 & 0.036 & 0.050 \\
Accrual & -0.124 & 3.441 & -0.111 & -0.041 & 0.015 \\
\hline
\end{tabular}

Panel A of Table 1 shows the descriptive statistics of the variables used in the khan and watts (2009) model. Sample consists of 4204 firm years over the period 1999 to 2013. The mean, SD (standard deviation), median, first and third quartiles are reported. Earn is net income before extra-ordinary items deflated by average total assets. $\mathrm{R}$ is showing the annual returns. Size is natural log of total assets. MTB represents market to book ratio, Lev is leverage defined as short term and long term debt scaled by total assets. Panel B provides descriptives of the variables used to estimate discretionary accruals. Cassets represents the non-cash current assets scaled by average total assets, Cliabilities represents the current liabilities without short term debt and tax payable scaled by average total assets. $\Delta$ Cassets represents the change in non-cash current assets scaled by average total assets. $\Delta$ Cliabilities is the change in current liabilities excluding change in short term debt and tax payable scaled by average total assets. Dep is the depreciation and Accrual is explained as ( $\Delta$ Cassets - $\Delta$ Cliabilities - Dep). Dep and Accrual both are scaled by average total assets.

\section{Estimation Results}

In this study, C-Score is calculated by employing a two-step process. In step one annual cross sectional regression is estimated using equation 4 . Then in the second step estimated annual coefficients from equation 4 are substituted in equation 3 for the firm year measurement of accounting conservatism.

Table 2 shows the descriptive statistics of C-Score. In this study the firms are divided into highly conservative and lesser conservative groups using quartiles.

Table 2. Descriptive statistics of C-score

\begin{tabular}{cccccc}
\hline & Mean & SD & $\mathrm{Q}_{1}$ & Median & $\mathrm{Q}_{3}$ \\
\hline C-Score & 0.061 & 0.738 & -0.008 & 0.054 & 0.109 \\
\hline
\end{tabular}

Note. The table shows the descriptives of C-Score. Mean, SD (standard deviation), median, first and third quartile is shown. 
The resultant two groups of 86 high conservative firms $\left(\mathrm{C}-\mathrm{Score}_{\mathrm{it}}>\mathrm{Q}_{3}\right)$ and 231 less conservative firms $\left(\mathrm{C}-\mathrm{Score}{ }_{\mathrm{it}}<\right.$ $\left.\mathrm{Q}_{3}\right)$ are shown in Table 3. Less conservative group includes 151 moderately conservative $\left(\mathrm{Q}_{1}<\mathrm{C}-\mathrm{Score}_{\mathrm{it}}<\mathrm{Q}_{3}\right)$ and 80 least conservative firms $\left(\mathrm{C}-\mathrm{Score}_{\mathrm{it}}<\mathrm{Q}_{1}\right)$.

Table 3. Groups based on level of conservatism

\begin{tabular}{lcc}
\hline Level of Conservatism & Number of Firms & Percentage \\
\hline Highly Conservative Firms & 86 & 27 \\
Less Conservative Firms & 231 & 73 \\
\hline Total & 317 & 100 \\
\hline
\end{tabular}

Table 3 shows that out of a sample of 317 firms, 86 firms are highly conservative, which is 27 percent of the total. While 231 firms are less conservative, which is 73 percent of the total number of firms. It shows that on the average the firms are not highly conservative.

Table 4. Descriptive statistics

Panel A. Highly conservative firms

\begin{tabular}{lcccc}
\hline & Mean & SD & $\mathrm{Q}_{1}$ & Median \\
\hline Earn & 0.099676 & 0.165534 & 0.015836 & 0.076779 \\
R & 0.436832 & 3.298318 & -0.10774 & 0.25056 \\
Size & 22.10015 & 1.730189 & 20.84813 & 22.03189 \\
Lev & 1.252779 & 21.96897 & 0.30021 & 0.48574 \\
MTB & 1.534285 & 5.201865 & 0.336372 & 0.622143 \\
\hline
\end{tabular}

Panel B. Lesser conservative firms

\begin{tabular}{lccccc}
\hline & Mean & SD & Q $_{1}$ & Median & Q $_{3}$ \\
\hline Earn & 0.057699 & 0.138584 & -0.00187 & 0.038344 & 0.113585 \\
R & 0.429834 & 2.349648 & -0.09628 & 0.235851 & 20.94593 \\
Size & 21.00288 & 1.467724 & 20.09375 & 0.659211 \\
Lev & 0.681659 & 0.358489 & 0.510184 & 0.662918 \\
MTB & 1.458341 & 6.801903 & 0.33771 & 0.69302 & 0.785999 \\
\hline
\end{tabular}

Panel A of Table 4 shows the descriptives of the highly conservative firms, while Panel B shows the statistics of lesser conservative firms. The mean, SD (standard deviation), median, first and third quartiles are reported. Earn is net income before extra-ordinary items deflated by average total assets. $\mathrm{R}$ is showing the annual returns. Size is natural $\log$ of total assets. MTB is the market to book value ratio, Lev is leverage defined as short term and long term debt scaled by total assets. Table 4 shows the descriptives of the two groups of firms i.e.; highly conservative and less conservative firms.

Discretionary accruals is used as a proxy to estimate the $E M$ in firms. The firms are divided into three groups based on the level of EM. First group consists of the firms that show high level of $E M$ (Discretionary accruals $>\mathrm{Q}_{3}$ ), second group consists of the firms that show moderate level of $E M\left(\mathrm{Q}_{1}<\right.$ Discretionary accruals $\left.<\mathrm{Q}_{3}\right)$ and the third group consists of firms that show least level of $E M$ (Discretionary accruals $<\mathrm{Q}_{1}$ ) as shown in Table 5.

Table 5. Levels of earning management

\begin{tabular}{lcc}
\hline Level of Earning Management & Number of Firms & Percentage \\
\hline High Earning Management & 73 & 23 \\
Moderate Earning Management & 155 & 49 \\
Least Earning Management & 89 & 28 \\
\hline Total & 317 & 100 \\
\hline
\end{tabular}

Table 5 shows the level of earning management in a sample of 317 firms. There are 73 firms that are involved in 
earning management at a higher level (Earning management $>\mathrm{Q}_{3}$ ), which is 23 percent of the total. There are 155 firms, i.e.; $49 \%$ of the total, that are involved in moderate earning management $\left(\mathrm{Q}_{1}<\right.$ Earning management $\left.<\mathrm{Q}_{3}\right)$ while 89 firms i.e.; $28 \%$ of the total, show least level of earning management (Earning management $\left\langle Q_{1}\right.$ ). This shows that earning management is pervasive but not at a higher level.

$E M$ is so much pervasive in the system that all firms are involved in it at various levels as shown in table 5. There are $23 \%$ firms (73 firms) that show high level of $E M, 49 \%$ (155 firms) show EM at a moderate level and $28 \%$ firms (89 firms) show least level of $E M$.

The firms with high $\left(\mathrm{C}-\mathrm{Score}_{\mathrm{it}}>\mathrm{Q}_{3}\right)$ and least $\left(\mathrm{C}-\mathrm{Score}_{\mathrm{it}}<\mathrm{Q}_{1}\right)$ conservatism level are then examined to find out the level of $E M$ in them, whereas the moderately conservative firms $\left(\mathrm{Q}_{1}<\mathrm{C}-\mathrm{Score}_{\mathrm{it}}<\mathrm{Q}_{3}\right)$ reveal no pattern. The results are shown in Table 6.

Table 6. Empirical findings of conservatism and earning management

Panel A. High conservative firms

\begin{tabular}{lcc}
\hline Conservatism Level & Lesser Earning Management & Moderate Earning Management \\
\hline High Conservative Firms & 65 Firms & 21 Firms \\
& $76 \%$ & $24 \%$ \\
\hline
\end{tabular}

Panel B. Least conservative firms

\begin{tabular}{lcc}
\hline Conservatism Level & High Earning & Moderate Earning \\
Management & Management \\
\hline Least Conservative Firms & 57 Firms & 23 Firms \\
& $71 \%$ & $29 \%$ \\
\hline
\end{tabular}

Table 6 Panel A shows that there are $76 \%$ highly conservative firms that are less engaged in earning management. On the other hand $24 \%$ firms show high conservatism level and moderate earning management. It shows a negative relation between conservatism and earning management. Panel B shows that $71 \%$ least conservative firms show a high level of earning management, while $29 \%$ of least conservative firms show moderate earning management. These results indicate that there is a negative association between accounting conservatism and earning management.

Table 6 shows that the firms that are highly conservative, are less engaged in $E M$ as shown by the percentage of 76 . Similarly the firms that are least conservative are more engaged in $E M$ as shown by the percentage of 71 . These results are consistent with the findings of Lara (2012) and most recently F. Lin et al. (2014) that highly conservative firms are less involved in $E M$ while lesser conservative firms are more involved in $E M$. In a nutshell, the analysis suggests that on the average the firm's level of $E M$ and accounting conservatism are inversely proportional to each other. Further analysis shows that there are $24 \%$ of highly conservative firms that show moderate (not high) level of $E M$ while on the other hand $29 \%$ of least conservative firms show moderate (not low) level of $E M$. Both show that there is a negative relation between accounting conservatism and $E M$ as illustrated in Table 7 .

Table 7. Relationship: Conservatism and earning management

\begin{tabular}{lcc}
\hline Conservatism Level & Earning Management & Relationship \\
\hline Higher & Lesser & Negative \\
Lesser & Higher & Negative \\
\hline
\end{tabular}

Table 7 shows an inverse association between conservatism and earning management. As higher the conservatism level lesser is the earning management while lesser the conservatism level the higher is the earning management.

\section{Conclusion}

The study employed a sample of 317 non-financial Pakistani firms consisting of 4204 firm year observations to find out the firm level accounting conservatism and EM. These firms are categorized into highly conservative and lesser conservative groups by applying C-Score measure developed by Khan and Watts (2009). On the other hand, 
discretionary accruals is used as a proxy for estimation of $E M$ using the method developed by Chan et al. (2001). The results show that there are $27 \%$ highly conservative firms ( 86 firms) while $73 \%$ lesser conservative firms (231 firms); showing that the firms on the average are not highly conservative. Out of these highly conservative firms $76 \%$ firms (65 firms) showed least $E M$ (Earning management $<\mathrm{Q}_{1}$ ) while $24 \%$ firms (21 firms) showed moderate $E M\left(\mathrm{Q}_{1}<\right.$ Earning management $\left.<\mathrm{Q}_{3}\right)$. Out of the least conservative firms $71 \%$ (57 firms) show high $E M$ (Earning management $>\mathrm{Q}_{3}$ ) and $29 \%$ (23 firms) show $E M$ at a moderate level $\left(\mathrm{Q}_{1}<\right.$ Earning management $\left.<\mathrm{Q}_{3}\right)$. Thus, overall findings show a negative relationship between $E M$ and the level of corporate accounting conservatism. In this study, we investigated company's accounting conservatism and $E M$ at different levels in order to provide assistance to the investors so that they become able to understand the influential role of different levels of accounting conservatism on corporate $E M$.

The essential point of conservatism is that the manager should fairly adopt conservatism level when preparing annual financial statements so as to minimize the earning management tactics, thus reducing information asymmetry.

\section{References}

Abed, S., Al-Badainah, J., \& Serdaneh, J. A. (2012). The Level of Conservatism in Accounting Policies and Its Effect on Earnings Management. International Journal of Economics and Finance, 4(6), 78. http://dx.doi.org/10.5539/ijef.v4n6p78

Ball, R., \& Shivakumar, L. (2005). Earnings quality in UK private firms: Comparative loss recognition timeliness. Journal of Accounting and Economics, 39(1), 83-128. http://dx.doi.org/10.1016/j.jacceco.2004.04.001

Ball, R., Robin, A., \& Sadka, G. (2008). Is financial reporting shaped by equity markets or by debt markets? An international study of timeliness and conservatism. Review of Accounting Studies, 13(2-3), 168-205. http://dx.doi.org/10.1007/s11142-007-9064-x

Basu, S. (1997). The conservatism principle and the asymmetric timeliness of earnings. Journal of Accounting and Economics, 24(1), 3-37. http://dx.doi.org/10.1016/S0165-4101(97)00014-1

Beaver, W. H., \& Ryan, S. G. (2005). Conditional and Unconditional Conservatism: Concepts and Modeling. Review of Accounting Studies, 10(2-3), 269-309. http://dx.doi.org/10.1007/s11142-005-1532-6

Chan, K., Chan, L. K., Jegadeesh, N., \& Lakonishok, J. (2001). Earnings quality and stock returns: National bureau of economic research.

Chekili, S. (2012). Impact of Some Governance Mechanisms on Earnings Management: An Empirical Validation Within the Tunisian Market.

Chen, Q., Hemmer, T., \& Zhang, Y. (2007). On the relation between conservatism in accounting standards and incentives for earnings management. Journal of Accounting Research, 45(3), 541-565. http://dx.doi.org/10.1111/j.1475-679X.2007.00243.x

DeAngelo, H., DeAngelo, L., \& Skinner, D. J. (1994). Accounting choice in troubled companies. Journal of Accounting and Economics, 17(1), 113-143. http://dx.doi.org/10.1016/0165-4101(94)90007-8

Dechow, P. M., \& Skinner, D. J. (2000). Earnings management: Reconciling the views of accounting academics, practitioners, and $\quad$ accounting Horizons, 14(2), 235-250. http://dx.doi.org/10.2308/acch.2000.14.2.235

Dyreng, S. D., Hanlon, M., \& Maydew, E. L. (2012). Where do firms manage earnings? Review of Accounting Studies, 17(3), 649-687. http://dx.doi.org/10.1007/s11142-012-9194-7

Fields, T. D., Lys, T. Z., \& Vincent, L. (2001). Empirical research on accounting choice. Journal of Accounting and Economics, 31(1-3), 255-307. http://dx.doi.org/10.1016/S0165-4101(01)00028-3

Givoly, D., Hayn, C. K., \& Natarajan, A. (2007). Measuring reporting conservatism. The Accounting Review, 82(1), 65-106. http://dx.doi.org/10.2308/accr.2007.82.1.65

Hamdan, A. M., Abzakh, M. H., \& Al-Ataibi, M. H. (2011). Factors Influencing the Level of Accounting Conservatism in the Financial Statements. International Business Research, 4(3), 145. http://dx.doi.org/10.5539/ibr.v4n3p145

Hazarika, S., Karpoff, J. M., \& Nahata, R. (2012). Internal corporate governance, CEO turnover, and earnings $\begin{array}{lllll}\text { management. Journal of } & \text { Financial }\end{array}$ http://dx.doi.org/10.1016/j.jfineco.2011.10.011 
Healy, P. M., \& Wahlen, J. M. (1999). A review of the earnings management literature and its implications for standard setting. Accounting horizons, 13(4), 365-383. http://dx.doi.org/10.2308/acch.1999.13.4.365

Khan, M., \& Watts, R. L. (2009). Estimation and empirical properties of a firm-year measure of accounting

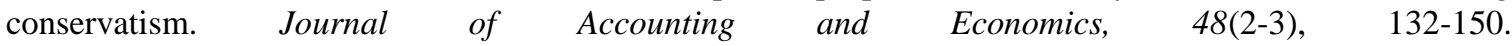
http://dx.doi.org/10.1016/j.jacceco.2009.08.002

Kravet, T. D. (2014). Accounting conservatism and managerial risk-taking: Corporate acquisitions. Journal of Accounting and Economics, 57(2-3), 218-240. http://dx.doi.org/10.1016/j.jacceco.2014.04.003

Kwon, S. S., Yin, Q. J., \& Han, J. (2006). The effect of differential accounting conservatism on the "over-valuation" of high-tech firms relative to low-tech firms. Review of Quantitative Finance and Accounting, 27(2), 143-173. http://dx.doi.org/10.1007/s11156-006-8794-3

LaFond, R., \& Watts, R. L. (2008). The Information Role of Conservatism. The Accounting Review, 447-478. http://dx.doi.org/10.2308/accr.2008.83.2.447

Lara, J. M. G., Osma, B. G., \& Penalva, F. (2012). Accounting conservatism and the limits to earnings management. Working Papers Series, pp. 1-55.

Lev, B. (1989). On the Usefulness of Earnings and Earnings Research: Lessons and Directions from Two Decades of Empirical Research. Journal of Accounting Research, 27, 153-192. http://dx.doi.org/10.2307/2491070

Lin, F., Wu, C. M., Fang, T. Y., \& Wun, J. C. (2014). The relations among accounting conservatism, institutional investors and earnings manipulation. Economic Modelling, 37(0), 164-174. http://dx.doi.org/10.1016/j.econmod.2013.10.020

Lin, Z. J., \& Tian, Z. (2012). Accounting conservatism and IPO underpricing: China evidence. Journal of International Accounting, Auditing and Taxation, 21(2), 127-144. http://dx.doi.org/10.1016/j.intaccaudtax.2012.07.003

Lobo, G. J., Parthasarathy, K., \& Sivaramakrishnan, S. (2008). Growth, managerial reporting behavior, and accounting conservatism. http://dx.doi.org/10.2139/ssrn.1098294

Marquardt, C. A., \& Wiedman, C. I. (2004). How Are Earnings Managed? An Examination of Specific Accruals. Contemporary Accounting Research, 21(2), 461-491. http://dx.doi.org/10.1506/G4YR-43K8-LGG2-F0XK

Peasnell, K. V., Pope, P. F., \& Young, S. (2005). Board monitoring and earnings management: Do outside directors influence abnormal accruals? Journal of Business Finance \& Accounting, 32(7-8), 1311-1346. http://dx.doi.org/10.1111/j.0306-686X.2005.00630.x

Schipper, K. (1989). Commentary on earnings management. Accounting Horizons, 3(4), 91-102.

Sloan, R. (1996). Do stock prices fully reflect information in accruals and cash flows about future earnings? (Digest summary). Accounting Review, 71(3), 289-315.

Sterling, R. R. (1967). Conservatism: The Fundamental Principle of Valuation in Traditional Accounting. Abacus, 3(2), 109-132. http://dx.doi.org/10.1111/j.1467-6281.1967.tb00375.x

Stolowy, H., \& Breton, G. (2004). Accounts manipulation: A literature review and proposed conceptual framework. Review of Accounting and Finance, 3(1), 5-92. http://dx.doi.org/10.1108/eb043395

Watts, R. L. (2003). Conservatism in accounting part I: Explanations and implications. Accounting Horizons, 17(3), 207-221. http://dx.doi.org/10.2308/acch.2003.17.3.207

Watts, R. L., \& Zimmerman, J. L. (1990). Positive Accounting Theory: A Ten Year Perspective. The Accounting Review, 65(1), 131-156. http://dx.doi.org/10.2307/247880

Zang, A. Y. (2011). Evidence on the trade-off between real activities manipulation and accrual-based earnings management. The Accounting Review, 87(2), 675-703. http://dx.doi.org/10.2308/accr-10196

\section{Copyrights}

Copyright for this article is retained by the author(s), with first publication rights granted to the journal.

This is an open-access article distributed under the terms and conditions of the Creative Commons Attribution license (http://creativecommons.org/licenses/by/3.0/). 